Research Article

\title{
Relationship between Preeclampsia and Low Birth Weight (LBW) in Wonosari, Gunungkidul Regional Hospital Year 2018
}

\author{
Dwi Wahyuni ${ }^{1}$ and Elika Puspitasari ${ }^{1, *}$ \\ ${ }^{1}$ Faculty of Health Sciences, 'Aisyiyah University, Yogyakarta, Indonesia \\ *Correspondence: elikapuspita@unisayogya.ac.id. Phone: +6287738254864
}

Received 26 October 2020; Accepted 20 February 2021; Published 21 February 2021

\begin{abstract}
Background: Globally, the infant and maternal mortality rate is still a severe problem because it was an indicator of national health - no exceptions for Indonesia. In 2017, the average infant mortality rate was 76 per 1,000 live births, while in Yogyakarta, it was 313 cases. The most common causes of infant and neonatal mortality were low birth weight babies (LBW) and sepsis. In 2018 in Wonosari, Gunungkidul Regional Hospital found 1,421 new-borns were normal, and 298 infants were experiencing LBW. This study aims to determine preeclampsia's relationship with the incidence of low-birth-weight babies (LBW) in Wonosari, Gunungkidul Regional Hospital Year 2018.
\end{abstract}

Method: This research was conducted in Wonosari, Gunungkidul Regional Hospital, using quantitative analysis with a case-control approach. The case population was 280 and using the Slovin formula. We recruited 170 controls and 170 cases. Inclusion criteria used include (1) Babies born with low birth weight <2,500 grams; (2) a single fetus; and (3) recorded in the medical record at the hospital.

Results: There was a significant relationship between preeclampsia with low-birth-weight babies (LBW) in Wonosari, Gunungkidul Regional Hospital 2018 with a p-value of 0.004 ( $p$ $<0.05)$ and crude OR 2.114; 95\% Cl (1.268-3.523).

Conclusion: Pregnant women with preeclampsia will be at greater risk of giving birth to a baby with LBW.

Keywords: Low birth weight; Preeclampsia; Pregnant women; Baby with LBW

\section{INTRODUCTION}

Globally, the infant mortality rate (IMR) and the maternal mortality rate (MMR) are still a severe problem because it was one of the national health indicators - including in Indonesia. Neonatal mortality in 2017 was about 2.5 million deaths or about $47 \%$ of all under-five mortality rates. Premature birth (born before 37 weeks' gestation) was blamed as the cause of low birth weight babies (LBW) (1), which is a new-born whose weight at birth was less than 2500 grams. The global prevalence of LBW is $15.5 \%$, which means that around 20 million LBW infants were born every year, and $96.5 \%$ LBW was born in developing countries (2). The definition of LBW could not only occur in premature babies but also in term infants who experience growth retardation during pregnancy (3). 
The 2012 Indonesian Demographic Health Survey (IDHS) showed neonatal mortality of 19 per 1,000 live births. The number of deaths in 2017 has decreased compared the neonatal mortality in 2012, which declined to 15 per 1,000 live births. The cause of death in the perinatal group was caused by Intra-Uterine Fetal Death (IUFD) by $29.5 \%$ and LBW by $11.2 \%$ (3).

According to the Special Region of Yogyakarta's health profile in 2017, the number of infant mortalities from 2014 to 2017 decreased from 405 to 278 in 2014-2016. Still, it increased in 2017 as many as 313. The common causes of infant and neonatal mortality in the Special Region of Yogyakarta were low birth weight babies (LBW) and sepsis. The prevalence of LBW in 2017, Kulon Progo was 6.69\%, Gunungkidul 5.67\%, Yogyakarta 5.16\%, Sleman 4.65\%, and the lowest was Bantul with $3.79 \%(4)$.

A previous study mentioned that LBW was caused by disease during pregnancy, one of which preeclampsia/eclampsia. Preeclampsia was a typical syndrome in pregnancy that affect the entire organ system due to decreased perfusion due to vasospasm and endothelial activation (5). General criteria for blood pressure preeclampsia $\geq 140 / 90 \mathrm{mmHg}$ that occur after 20 weeks' gestation and the presence of proteinuria $300 \mathrm{mg}$ or more urine protein per 24 hours or $30 \mathrm{mg} / \mathrm{dL}$ (1+ on dipstick) in random urine samples (6). Around 12-25\% results in limited fetal and small growth for gestational age and premature birth. Research in Palu, Indonesia, found a significant relationship between preeclampsia and LBW events with a p-value of 0.003 and a strength of relationship 0.215 (7). There was a statistically significant relationship, but there were probably other variables that were also more influential than the preeclampsia factor. Mothers who have experienced preeclampsia during pregnancy had a 2.48 times greater risk of giving birth to low birth weight (LBW) babies than mothers who did not experience preeclampsia.

A preliminary study conducted in January 2019 at Wonosari, Gunungkidul Regional Hospital found the number of patients with LBW infants from January - December 2018 was 298 babies with a total of 1,421 new-born babies. This research determined preeclampsia's relationship with the incidence of low-birth-weight babies (LBW) Wonosari, Gunungkidul Regional Hospital.

\section{METHOD}

This study was quantitative with a case-control approach that figure out in Figure 1 . The population of the study was 298 new-born babies with LBW in Wonosari, Gunungkidul Regional Hospital. The study's sample size was 170 sample cases grouped by the Slovin formula with a confidence level of 0.05 . The control group was 170 new-borns who did not experience LBW using a ratio of 1: 1 (8). The total sample of the study was 340 infants. Inclusion criteria were (1) Babies born with low birth weight <2,500 grams; (2) a single fetus; and (3) recorded in the medical record at the hospital. Exclusion criteria was (1) Intrauterine growth restriction (IUGR); (2) Twins; (3) LBW history; and (4) maternal age <20 and > 35 years. Data analysis uses Chi-square statistical tests. 


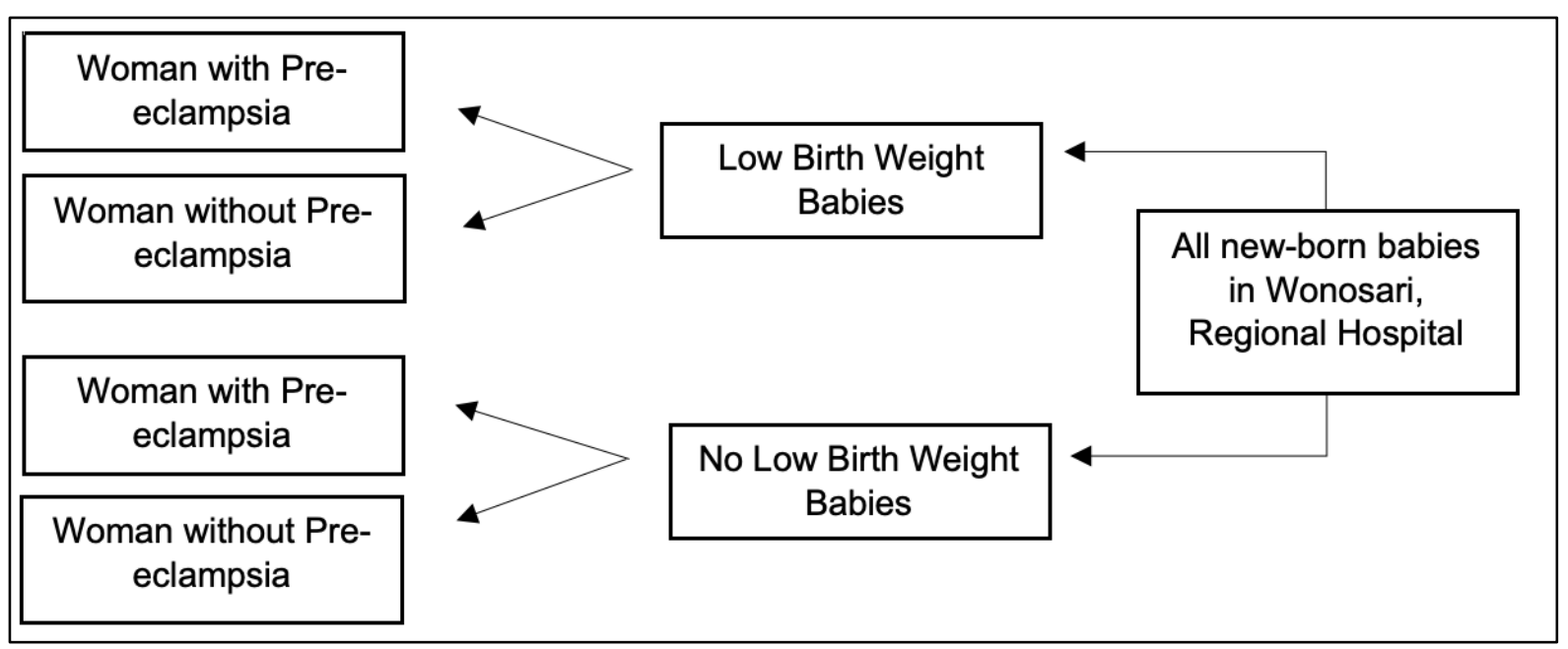

Figure 1. Data acquisition diagram

\section{RESULTS}

Table 1 shows respondents' characteristics based on maternal age in the case group; maternal age $20-35$ is $170(100 \%)$. In the control group, maternal age of $20-35$ years is 125 people $(73.5 \%)$ more than maternal age $>35$ years, which is 39 people $(24.1 \%)$, and maternal age $<20$ years is six people $(3,5 \%)$.

Table 1. Characteristics of Respondents in Wonosari, Gunungkidul Regional Hospital 2018

\begin{tabular}{lcccc}
\hline \multicolumn{1}{c}{ Characteristics } & \multicolumn{2}{c}{ Case } & \multicolumn{2}{c}{ Control } \\
\cline { 2 - 5 } & $\mathbf{n}$ & $\mathbf{0}$ & $\mathbf{n}$ & $\%$ \\
\hline Mother's Age & & & & \\
$\quad$ Age <20 years & 0 & 0 & 6 & 3.5 \\
$\quad$ Age 20-35 years & 170 & 100 & 125 & 73.5 \\
$\quad$ Age $>35$ years & 0 & 0 & 39 & 22.9 \\
$\quad$ Total & 170 & 100 & 170 & 100 \\
Parity & & & & \\
$\quad$ Primiparous & 79 & 46.5 & 58 & 34.1 \\
$\quad$ Multipara Multiparaous & 91 & 53.5 & 112 & 65.9 \\
$\quad$ Total & 170 & 100 & 170 & 100 \\
Age & & & & \\
$\quad$ Preterm & 94 & 55.3 & 46 & 27.1 \\
$\quad$ Aterm & 76 & 44.7 & 124 & 72.9 \\
$\quad$ Total & 162 & 100 & 162 & 100 \\
\hline
\end{tabular}

The respondents' characteristics based on parity in the case group, primipara, were 79 people $(46.5 \%)$ less than multipara, $91(53.5 \%)$. In the control group, primipara was 58 people (34.1\%) less than multipara, 112 people $(65.9 \%)$. Of the 340 respondents, the most common gestational age distribution in the case group was preterm gestational age, with 94 people $(55.3 \%)$ compared to term gestational age with 76 people $(44.7 \%)$. In the control group, preterm gestational age was 46 people $(27.1 \%)$, less than at term gestational age was 124 (72.9). 


\section{Table 2. Distribution of LBW and preeclampsia status in Wonosari, Gunungkidul Regional Hospital 2018}

\begin{tabular}{lcc}
\hline Variable & $\mathbf{n}$ & $\mathbf{( \% )}$ \\
\hline LBW status & & \\
$\quad$ LBW & 170 & 50 \\
$\quad$ Not LBW & 170 & 50 \\
Preeclampsia status & & \\
$\quad$ Preeclampsia & 83 & 24.4 \\
$\quad$ No Preeclampsia & 257 & 75.6 \\
\hline
\end{tabular}

Table 2 shows that the number of respondents in this study was 340 respondents $(100 \%)$ with the criteria of 170 respondents $(50 \%)$ as case samples in LBW infants and 170 respondents $(50 \%)$ as control samples for non-LBW infants. Women with preeclampsia were $83(24.4 \%)$ less than women with no preeclampsia - 257 people $(75.6 \%)$ out of 340 respondents.

Table 3. Distribution of Preeclampsia Frequency in Wonosari, Gunungkidul Regional Hospital 2018

\begin{tabular}{ccccccc}
\hline \multirow{2}{*}{ Variable } & \multicolumn{2}{c}{ LBW } & \multicolumn{2}{c}{ No LBW } & \multirow{2}{C}{$\begin{array}{c}\text { Crude OR } \\
(\mathbf{9 5 \%} \mathbf{C I})\end{array}$} & P-value \\
\cline { 2 - 5 } & $\mathbf{n}$ & $\mathbf{\%}$ & $\mathbf{n}$ & $\mathbf{\%}$ & & \\
\hline Preeclampsia & 53 & 31.2 & 30 & 17.6 & & 0.004 \\
No Preeclampsia & 117 & 68.8 & 140 & 82.4 & $(1.268-3.523)$ & \\
\hline
\end{tabular}

Table 3 shows that the respondents with LBW mostly came from a woman with no preeclampsia that was $117(68.8 \%)$. The same case occurred in infants with no LBW, which is higher than LBW infant $140(82.4)$.

Chi-square test obtained a p-value of $0.004(p<0.05)$. The results show a relationship between preeclampsia and LBW in Wonosari, Gunungkidul Regional Hospital. Odds Ratio analysis results, $\mathrm{OR}=2.114$, show that women who have preeclampsia are 2.114 times more at risk of giving birth with LBW than women who do not have preeclampsia.

\section{DISCUSSION}

Previous studies found that mothers age at risk to give birth to babies with LBW as many as $29(32.6 \%)$ was ( $<20$ and $>35$ years). Simultaneously, a woman at 20-35 years has a low risk of as many as $60(67.4 \%)$. A study result obtained no difference in the proportion of LBW events between age at risk and not at risk (9). The results of this study were consistent with the theory that the risk of age for babies born with LBW is in mothers aged $<20$ years due to lack of perfection both physically and mentally and at age $>35$ years because at this age, the functions of the reproductive organs are experiencing setback so that the risk of giving birth to LBW is higher (10)(11).

The results of this study showed that not only mothers with multipara parity gave birth to babies with LBW but also mothers with primiparous parity had the opportunity to deliver babies with LBW. In this study, primiparous and multiparous mothers almost had the same opportunity to deliver babies with LBW. Primiparous mothers or having a first-time pregnancy do not have pregnancy experience. The abnormalities and complications experienced are quite significant 
such as dystocia of labor, low nutritional status, and lack of information about pregnancy that will affect the baby's weight (12).

The results of previous studies indicate that gestational age $<37$ weeks at 143.5 times the risk of having a low birth baby (9). This is in line with a previous study that found a significant relationship between gestational age, multiple pregnancies, hypertension, and severe anemia during pregnancy with LBW events (13)(14). This is due to partial or complete detachment of the placenta from normal implantation, a history of disease during pregnancy, and uterine abnormalities due to genetic factors (15). Other causative factors include preeclampsia, acute infection, strenuous physical activity, multiple births, stress, anxiety, and other psychological factors $(10)(16)$. This is consistent with the theory that babies born at less than 37 weeks' gestational age are at risk for LBW birth due to growth imbalances due to impaired placental circulation and chronic nutritional deficiencies. The birth of a baby with LBW at term gestational age can be caused by other factors such as parity 2 or 4 , the lack of understanding of mothers regarding pregnancy care, and the mother's nutritional status. Age 37 weeks' gestation is an excellent gestational age for the fetus (10)(17).

Based on the bivariate analysis conducted to test preeclampsia's relationship with LBW using the Chi-square test, the p-value was 0.04 . The results show an association between preeclampsia and LBW events because the $p$-value is smaller than $\alpha(0.04<0.005)$. This result is in line with previous research with a $p$-value of 0.001 . There is a significant relationship between severe preeclampsia with the incidence of low-birth-weight babies at Dr.Oen Hospital Surakarta (18). Preeclampsia and eclampsia are a group of diseases directly caused by pregnancy, the cause of which is unclear. In addition to infection and bleeding, preeclampsia and eclampsia are fundamental causes of maternal and perinatal death in obstetrics (19). This study's results are in line with research conducted by Hartati in 2018 in Wangaya District Hospital with a p-value of 0.00 , indicating there is a relationship between preeclampsia mothers with low birth weight, with an OR value of 4.752 (20). Meaning that women with preeclampsia risk their babies will experience babies with LBW. And also supported by previous studies that showed that preeclampsia could increase the risk of IUGR and low birth weight due to decreased uteroplacental blood flow, and this will cause the outcome of low birth babies (21).

Mothers with preeclampsia were at risk of giving birth to a baby with LBW. In preeclampsia, abnormalities of the placenta and vasospasm, and endothelial injury will occur. Preeclampsia will fail in the invasion of trophoblasts in both waves of the spiral arteries. There would be a failure of spiral artery remodeling, which results could decrease uteroplacental blood flow. Reduced blood flow to the uteroplacental could cause hypoxia and placental ischemia, resulting in stunted fetal growth (22) - supported previous research that states mothers with preeclampsia were four times at risk of giving birth to babies with LBW (20). Based on the study, 117 mothers did not have preeclampsia as many as 117 mothers who gave birth to LBW babies. Another cause of LBW from maternal factors was the birth spacing that was too short (less than one year), low socioeconomic conditions (23).

Two previous studies mentioned that the risk factors for giving birth to a baby with LBW had an association with anemia and placental abnormalities to the incidence of premature LBW and desaturation while risk factors for parity, pregnancy spacing, maternal medical illness (hypertension, preeclampsia, diabetes, and infection), obstetric history and maternal 
nutritional status that were stated to be no statistically significant relationship between premature LBW and desaturation $(24,25)$.

\section{CONCLUSION}

Based on the research results, we conclude that the incidence of preeclampsia frequency in Wonosari, Gunungkidul Regional Hospital in 2018 was 83 people (24.4\%), while those who did not preeclampsia were 257 people $(75.6 \%)$. There is a relationship between preeclampsia and the incidence of LBW with a p-value of $0.04<0.05$.

\section{Authors' Contribution}

EP contributed to research design and developed the first draft of the manuscript. DW contributed to the data collection and statistical analysis.

\section{Funding}

The researcher was grateful to LPPM Universitas 'Aisyiyah Yogyakarta for supporting materially and morally so that this research can be carried out well.

\section{Conflict of interest}

There is no conflict of interest.

\section{REFERENCES}

1. WHO. WHO Recommendation on Midwife-led Continuity of Care During Pregnancy. 2016.

2. WHO. Newsborns: Reducing Mortality. 2018.

3. Kementerian Kesehatan Republik Indonesia. Profil Kesehatan Indonesia. Profil Kesehatan Provinsi Bali. Jakarta; 2016. 1-220 p.

4. Dinas Kesehatan Provinsi DIY. Profil Kesehatan Provinsi DIY. 2017.

5. Hasriyani. Hadisaputro, S. Budhi, K. Setiawati, M. and Setyawan H. Berbagai Faktor Risiko Kejadian Bayi Berat Lahir Rendah (BBLR) Studi di Beberapa Puskesmas Kota Makassar. Universitas Diponegoro Semarang; 2018.

6. Cunningham F. Obstetri Williams. Edisi 23. Jakarta: EGC; 2010.

7. Mallisa B, Towidjojo VD. Hubungan Antara Preeklampsia Dengan Kejadian Bayi Berat Badan Lahir Rendah di RSUD Undata Palu. J IIm Kedokt. 2014;1(3):1-7.

8. Saryono. Metodologi Penelitian Kuantitatif dan Kualitatif. Bandung: Alfabeta; 2010.

9. Sujianti. Hubungan Usia Ibu Dengan Kejadian Bayi Berat Lahir Rendah (BBLR) di RSUD Cilacap. J Kesehat Al-Irsyad. 2018;XI(1).

10. Manuaba IBG. IImu Kebidanan, Penyakit Kandungan dan Keluarga Berencana Untuk Pendidikan Bidan. Jakarta: EGC; 2012.

11. Owa K, Eka Putra IWGA, Trisna Windiani IG. Risk factors for low birth weight infants in East Nusa Tenggara. Public Heal Prev Med Arch. 2017;5(1):49.

12. Edriana., D.S. Indrawati, D.N. and Rahmawati A. Hubungan Umur dan Paritas Ibu dengan Berat Badan Lahir d RB Citra Insani Semarang. J UNIMUS. 2013;2(1).

13. Purwanto AD and WCU. Hubungan Antara Umur Keamilan,Kelamilan Ganda, Hipertensi Dan Anemia Dengan Kejadian BBLR. J Berk Epidemiol. 2016;4(3).

14. Ali AA, Rayis DA, Abdallah TM, Elbashir MI, Adam I. Severe anemia is associated with a higher risk for preeclampsia and poor perinatal outcomes in Kassala hospital, eastern Sudan. BMC Res Notes. 2011;4(1):311. Available from: http://www.biomedcentral.com/1756-0500/4/311. 
15. Rahmi. Arsyad. and Rismayanti. Faktor-Faktor yang Berhubungan dengan Kejadian Bayi Berat Badan Lahir Rendah Di RSIA Pertiwi Makassar. J Epidemiol FKM Univ Hasanudin.

16. Takiuti NH, Kahhale S, Zugaib M. Stress in pregnancy: A new Wistar rat model for human preeclampsia. Am J Obstet Gynecol. 2002;186(3):544-50.

17. Insoft RM, Todres DI. Gestational Age. Science Direct. 2009 [cited 2021 Feb 18]. Available from: https://www.sciencedirect.com/topics/medicine-and-dentistry/gestationalage.

18. Utami U. Hubungan Antara Preeklampsia Berat dengan Kejadian Bayi Berat Lahir Rendah (BBLR) Di RS DR. OEN Surakarta. Universitas Muhammadiyah Surakarta; 2017.

19. Sofian A. Sinopsis Obstetri Fisiologi. Yogyakarta: EGC; 2013.

20. Hartati NN, Surinati IDAK, Pradnyaningrum NNDV. Preeklampsia dengan Berat Badan Lahir Rendah (BBLR) pada Ibu Bersalin. Gema Keperawatan. 2018;11(1):1-9.

21. Backes, C.H. Kara, M. Pamela, M. Leandro, C. Craaig, A.N. Peter J. Maternal Preeclampsia and Neonatal Outcomes. J Pregnancy. 2011;1.

22. Prawirohardjo S. IImu Kebidanan. Edisi ke-4. Jakarta: PT Bina Pustaka; 2010.

23. Proverawati A and I. BBLR (Berat Badan Lahir Rendah). Yogyakarta: Nuha Medika; 2010.

24. Benedict O IKN. Maternal Risk Factors Associated with Low Birth Weight Neonates: A Multi-Centre, Cross-Sectional Study in a Developing Country. J Neonatal Biol. 2015;04(03).

25. Singh G, Chouhan R, Sidhu K. Maternal factors for low birth weight babies. Med J Armed Forces India. 2009;65(1):10-2. Available from: http://dx.doi.org/10.1016/S03771237(09)80045-2. 